\title{
УДК 17.2-46/.364-1
}

\author{
М. М. ЖИТНИК ${ }^{1 *}$ \\ 1*Національний технічний університет України «Київський політехнічний інститут імені Ігоря Сікорського» (Київ), \\ ел. пошта Maryna_zhytnyk@i.ua, ORCID 0000-0003-3374-0091
}

\section{БЛАГОДІЙНІСТЬ У ПРОЦЕСІ ФОРМУВАННЯ ГУМАНІСТИЧНОЇ АКСІОСФЕРИ ГРОМАДЯНСЬКОГО СУСПІЛЬСТВА}

Метою роботи є характеристика благодійності як складової громадянського суспільства, що розвивається на основі принципу гуманізму в сучасному суспільстві. Методологія статті грунтується на комплексному дослідженні в діалектичній взаємодії тріалогу одиничного, особливого та загального, що дало можливість розглянути окремі явища в розвитку та взаємозв'язку, єдності та протиріччях, зокрема під час вивчення та аналізу окремих понять. 3 метою уявного відходу від несуттєвих властивостей зв'язків, які характеризують окремі поняття, з одночасним виділенням їх найважливіших рис було використано метод абстрагування та індукції. Наукова новизна роботи полягає в тому, що вперше було окреслено взаємозв'язок методологічних підходів та різнопланових практичних версій розвитку благодійності та життєздатностей громадянського суспільства на основі гуманістичного принципу. Розроблена та запропонована до використання ієрархічна піраміда благодійності, критеріями розміщення елементів якої $є$ створення найбільш сприятливих умов для практичного розвитку людини в цілому та ії гуманістичних якостей зокрема, що співставлється та $є$ прямозалежною 3 пірамідою потреб А. Маслоу. Введено та розтлумачено поняття «активна благодійність» як діяльність, що комплексно вирішує проблеми соціального характеру. Висновки. Благодійність, як інституційна та ресурсна складова громадянської діяльності, виступає одним із практичних шляхів побудови суспільства на принципах гуманності, Однак, не всі форми благодійності є однаково ефективними. Представники активної благодійності, найвищого щабля ієрархічної структури благодійності, є фінансово-стабільні, свідомі особистості, що безпосередньо виступають практиками гуманізму та є найбільш результативними.

Ключові слова: благодійність; громадянське суспільство; гуманізм; євпраскофія; ієрархічна піраміда благодійності; активна благодійність.

\section{Актуальність}

Актуальність гуманізму в сучасному світі $\epsilon$ нагальною потребою часу. У науковій філософській світовій думці сформовано десятки теоретичних обгрунтувань необхідності функціонування гуманізму, як одного 3 основних принципів філософії. Зокрема, вперше проблема гуманізму яскраво була представлена теоретиком Ренесансу Піко де́лла Міра́ндоллою у роботі «Промова про гідність людини», де було засвідчено, що гуманізм - це проект розвитку Європейської свідомості на майбутні століття. Антропоцентричне бачення філософа $3 \mathrm{XV}$ століття залишається дійсним по сьогоднішній день. Адже до поки на планеті відбуватимуться війни й аморальні вичинки, що знищують, пригноблюють, знецінюють людину та іiі гідність, питання гуманізму завжди посідатиме чільне місце у рейтингу питань, що потребують вирішення.
Важливий принцип функціонування гуманізму був розроблений у діалектико матеріалістичній методологіі. Ми солідарні 3 думкою одного з сучасних вітчизняних філософів, представника даної методології, Б.В. Новікова [7] стосовно необхідності переведення гуманізму 3 форми теоретично обгрунтованої віртуальності у форму практично здійснюваної актуальності і вважаємо за необхідне розкрити дану проблематику у нашому дослідженні. Більше того, дискусія навколо гуманізму і його долі в сучасному світі вказує не лише на глибоку економічну кризу, яка зараз існує, але i на його важливе значення для всієї історії людства.

Важливо зазначити, що першочерговою та необхідною складовою вирішення проблемних питань є їх теоретичне осмислення. Але, воно (теоретичне осмислення) діалектично має переходити в практику, без якої теоретичне дослідження залишається виключно абстрактним філософуванням соціокультурних, симсложиттєвих, екзистенційних вимірів буття, що не 
трансформується в дійсну практику філософського наукового пізнання та знання.

Сучасний стан військових дій на території нашої держави та палаючих регіонів світу свідчить, що суспільство має звернутися до теорій та практик гуманізму. Саме наукові теорії та практики мають сконцентруватися на осмисленні цінностей i шляхів гуманістичного існування людської цивілізації. У цьому аспекті проблему гуманізму соціуму можна вирішити розкриваючи багатопланові можливості благодійності, як умови і механізму функціонування сучасного громадянського суспільства.

\section{Мета}

Тому, метою статті є характеристика благодійності як складової громадянського суспільства, що розвивається на основі принципу гуманізму в сучасному суспільстві.

По при всі науково-філософські обгрунтування дана проблематика потребує подальшого дослідження. Оскільки наука займалася детальною розробкою кожної області - гуманізм, благодійність, громадянське суспільство - окремо. Гуманізм - Арістотель, Демокріт, Епікура, Лукреційй, Перікл, Ф. Беконом, Боккаччо, Е. Роттердамським, Монтенем, Т. Мор, Петрарка, М. Бердяєв, І. Борзенько, А. Горєлов, В. Кувакін, В. Гузенко, А. Здравомислова, Н. Кіяшко, А. Круглова,У.А. Сміт, П. Куртц, К. Ламонт, В. Лейбіка; благодійництво - Сенека, Гегель, Т. Гоббса, I. Канта, Т. Адорно, К. Маркс, Ф. Енгельс, П. Лафарг, Дж. Мілль, Н. Бердяєва, М. Бубера, Д. Гільдебранда, Г. Йонаса, Е.Левінаса, К. Л'юіса, Е. Макінтайра, П. Рікера, Дж. Ролза, Е.Фрома, О. Гьоффе, А.Швейцера та А. Прокоф'єва,Т. Василевської, А.Срмоленка, С. Кримського, В. Малахова; громадянське суспільство - Платон, Арістотель, Д. Гоббс, Дж. Локк, Ш.Л. Монтеск'є, І. Кант, Ф. Гегель, К. Маркс, Ф. Енгельс, Дж. Кін, А. де Токвіль, Е. Арато та Дж. Коен, М. Драгоманов, I. Франко, М. Грушевський, Б. Кістяківський, М. Шаповал, Ю. Габермаса, Е. Арато, Дж. Коена, Р.Д. Пантема, А. Грамші, А. Алексанян, К. Гаджієв, В. Степаненко, Ф. Хайєк, Є. Шацький, В. Нерсесянц.

Сучасний стан розвитку суспільства вимагає їхнього комплексного дослідження в діалектичній взаємодії тріалогу одиничного, особливого та загального. Де загальним є громадянське суспільство, одиничним - благодійність, особливим
- гуманізм.

\section{Виклад основного матеріалу}

Гуманізм (від лат. «Номо» - людина, «humanus» - людський, людяний, «humanitas» людська природа) - особливий тип філософського світогляду, в центрі якого людина з їі земними справами і звершеннями, 3 властивими ii природі здібностями і схильностями, з характерними для неї нормами поведінки і відносинами. У широкому сенсі слова гуманізм - це доброзичливе ставлення до людини, яке утверджує іiі свободу і гідність незалежно від будь-яких виконуваних нею соціальних функцій i ролей та вбачає в ньому самостійне джерело творчих сил [4].

Широке трактування даного поняття в сучасній філософській науці засвідчує, що своїм виникненням воно зобов'язане перш за все культурній практиці Відродження, яке заклало початок абсолютно нової - гуманістичноантропоцентричної культури, багато в чому протилежної клерикальній культурі Середньовіччя 3 iii пануванням релігії i церкви в духовних i мирських справах.

Якщо одні західні історики (напр., П.О. Крістеллер) вбачають в гуманізмі епохи Відродження всього лише технічний термін, що позначає певну педагогічну і культурну програму, набір дисциплін гуманітарного профілю (граматика, риторика, історія, поетика, етика і ін.), то інші (Е. Гарен), полемізуючи 3 цим, надають цьому явищу насамперед філософський сенс, бачачи в ньому принципово нове у порівнянні 3 середньовічним розуміння природи і призначення людини. За словами Я. Буркхардта, «саме в Італії епохи Відродження людина і людство були вперше пізнані в повній мірі і в їх найглибшій сутності. Вже одного цього достатньо, щоб бути вдячним Ренесансу. Логічне поняття людського (Menschheit) iснувало 3 давніх пір, але тільки Відродження повною мірою пізнало суть цього поняття» $[5$, с. 58].

На відміну від античного космоцентризму i середньовічного теоцентризму новоєвропейський гуманізм відстоює антропоцентричну картину світу, в якій людина займає самостійне («серединне») місце між Богом і природою, небесним і земним. В різноманітті знань про зовнішній світ і Бога знання про природу самої людини гуманізм вважав вищим і єдино доступ- 
ним для людей видом знання, стверджуючи при своєму виникненні пріоритет гуманітарного знання перед природничим, 3 одного боку, i ceредньовічною схоластикою - 3 іншого [6, с. 77 104].

Людина розглядається як вільна істота, здатна творити саму себе, надавати собі тієї форми, яку вона сама забажає як суб'єкт пізнання i діяльності, що у своїх діях керується власним розумом і творчим потенціалом. У цьому полягало головне відкриття гуманізму, яке отримало розвиток в раціоналістичній парадигмі. Нового часу, яка утвердила вирішальне значення людського розуму як в пізнанні світу, так і в створенні суспільно-політичних форм людського співжиття. У розвитку соціально-філософської думки це відобразилося у виникненні певного гуманістичного ідеалу особистості як вільної індивідуальності, здатної до творчого самоздійснення, мрії про суспільство, в якому ці можливості будуть повністю реалізовані, що призвело до виникнення перших соціальних утопій (Т. Мор, Т. Кампанелла і ін.).

В соціально-філософській думці ХХ ст. гуманізм зберігає значення основоположної культурної цінності, з позиції якої ведеться критика капіталізму як суспільства, що виключає справжню свободу i автономію людини, що підпорядковує своїй владі раціонально організовані сили у вигляді фінансово-промислових корпорацій, політичної бюрократії і електронних засобів масової інформації. Така критика характерна для багатьох напрямків лівого спрямування і різних представників неофрейдистів, зокрема Франкфуртської школи (М. Хоркхаймер, Т. Адорно, Г. Маркузе, Е. Фромм, Ю. Хабермас) i iн.

Пошуки нових форм гуманізму, відповідних духу часу, велися в західній філософії першої половини XX ст. як в неоязичництві, так і в християнській, католицькій, протестантській думці (К. Барт, Річард Нібур, П.Тілліх) та неотомістському проекті «інтегрального гуманізму» Ж. Марітена.

Зазначимо, що вченими XX ст. було запропоновано декілька варіантів систематизування гуманізму, враховуючи його історичний розвиток. Ми вважаємо однією 3 найгрунтовніших класифікацій є класифікація запропонована У.А. Смітом, який у 1949 р. виокремив сім видів гуманізму і дав їм детальну характеристику у своїй роботі «Хто є хто в пеклі: Довідник і міжнародна адресна книга для гуманістів, вільнодумних, натуралістів, раціоналістів і нетеїстів». До класифікації увійшли:

- гуманізм - поняття, що означає ставлення до людських інтересів або до вивчення гуманітарних дисциплін (study of the humanities);

- античний гуманізм - поняття, що відноситься до систем філософії Арістотеля, Демокріта, Епікура, Лукреція, Перікла, Протагора або Сократа;

- класичний гуманізм - поняття, що відноситься до древніх гуманістичних ідей, які започатковані Ф. Беконом, Боккаччо, Е. Роттердамським, Монтенем, Т. Мор і Петраркою у період Ренесансу;

- теїстичний гуманізм - поняття, яке включає в себе як християнських екзистенціалістів, так i тих сучасних теологів, які наполягають на здатності людини працювати над своїм порятунком спільно з Богом;

- атеїстичний гуманізм - поняття, яке описує творчість Жан-Поля Сартра та ін.;

- комуністичний гуманізм - поняття, що характеризує переконання деяких марксистів (наприклад, Ф.Кастро або колишнього секретаря Л. Троцького Раї Дунаєвської), які вважають, що послідовним натуралістом і гуманістом був К. Маркс;

- натуралістичний (або науковий) гуманізм еклектичний набір установок, народжених в сучасну наукову епоху і сконцентрованих на вірі в найвищу цінність і самовдосконалення людської особистості [11, с. 542].

Останній, сьомий, вид гуманізму за У.А. Смітом придбав широку популярність в 50-х роках XX ст.. Своєю популярністю він був зобов'язаний діяльності американських філософів Сідні Хука і Корлісса Ламонта. Хук відзначав, що натуралістичний гуманізм відрізняється від теїстичного гуманізму запереченням будь-якої форми супранатуралізму, від атеїстичного прагненням уникнути виставлення себе напоказ, від комуністичного - опозицією до всіх усталених переконань, що не засновані на ідеї свободи, важливості індивідуальної та політичної демократії (11, с. 543). Натуралістичний гуманізм Хука і Ламонта став основою для становлення такого виду гуманізму, як світський гуманізм. Зупинимося докладніше на поглядах Ламонта найгрунтовнішого представника філософського 
руху натуралістичного гуманізму.

Однією $з$ найбільш відомих праць К. Ламонта $є$ книга «Філософія гуманізму», що вперше була опублікована під назвою «Гуманізм як філософія» 1947 р., та до сьогоднішнього дня має вісім перевидань. Своє філософське кредо Ламонт виклав в «десяти твердженнях гуманістичної філософії». За його словами, ці тези дозволяють дати визначення філософії гуманізму, а також відокремити іiї від інших світоглядних напрямків. Ламонт стверджував, що:

1. всі форми надприродного є міфом, а природа (nature), як існуюча незалежно від свідомості знаходиться в постійній зміні системи матерії і енергії та становить повноту буття;

2. людина є продуктом природної еволюції, iї свідомість нерозривно пов'язана 3 діяльністю мозку і не має шансів вижити після смерті;

3. люди мають здатність вирішувати власні проблеми, керуючись розумом і застосовуючи науковий метод;

4. люди, хоча і пов'язані з минулим, але, тим не менше, мають свободу творчого вибору і дії;

5. етика складає основу всіх людських цінностей у формах досвіду і видах відносин;

6. індивід досягає блага, гармонійно поєднуючи особисті бажання і безперервний саморозвиток з роботою, що робить внесок у добробут суспільства;

7. необхідний якомога ширший розвиток мистецтва і естетичний досвід може стати однією 3 основних реальностей в житті людей;

8. необхідна довгострокова соціальна програма, яка передбачає встановлення в усьому світі демократії, миру і високого рівня життя;

9. повне здійснення розуму і наукового методу можливо в усіх галузях економічного, політичного і культурного життя;

10. гуманізм - це не нова догма, але філософія, що постійно розвивається і завжди залишається відкритою до експериментальної перевірки, нових фактів і більш суворих міркувань.

За словами Ламонта «ці десять пунктів втілюють гуманізм в його найбільш прийнятній сучасній формі. Ця філософія більш точно може бути охарактеризована як науковий гуманізм, світський (secular) гуманізм, натуралістичний гуманізм або демократичний гуманізм, в залежності від акценту, який йому прагнуть надати» [10, c. 11-12].
Вагомий внесок у розвиток світського гуманізму належить американському філософу та Президенту Міжнародної академії гуманізму П. Куртцу. У 2000 р. у своїй книзі «Мужність стати: чесноти гуманізму» Куртц пропонує виділити п'ять наступних стрижневих (core) ознак гуманізму:

- гуманізм пропонує набір цінностей і чеснот, що випливають 3 визнання людської свободи і самостійності. Етика гуманізму протистоїть релігійно-авторитарній етиці;

- гуманізм заперечує ідею надприродного;

- гуманізм базується на методі дослідження, що спирається на розум і наукову об'єктивність;

- гуманізм має свою нередукціоністську природну онтологію, засновану на науковому знанні;

- справою філософів-гуманістів є не тільки питання теорії, а й втілення ідей гуманізму в практичному житті як альтернативи теїстичним релігіям [9, с. 110].

Важливо підкреслити, що дані принципи пов'язані логічним відношенням кон'юнкції, тобто під гуманізмом слід розуміти те, що підкоряється всім без винятку вищезазначеним ознакам.

Особливу увагу Куртц приділяє проблемам гуманістичної практики (п'ятий принцип). У зв'язку з цим він пропонує ввести нове поняття «євпраксофія» (eupraxsofia; від лат. еu - блаженство, praxis - практика i sofia - мудрість). Евпраксофія $є$ нерелігійною філософією або світоглядом, яке підкреслює, наскільки важливо жити яскравим і моральним життям, спираючись на такі раціональні методи, як логіка, спостереження і наука, а не віра, містицизм або одкровення. Поки гуманізм не стане реальною альтернативою релігійних культів, він «...ризикує залишитися одним з інтелектуальних рухів, до якого виявляють зацікавленість певна кількість вчених філософів, але які мають мінімальне відношення до живого жи, c. 124].

Таким чином, сучасний світський гуманізм заявляє про себе як про ідейний рух, у якому теорія і практика повинні бути нерозривно пов'язані і органічно доповнювали один одного.

На нашу думку, одним із шляхів беззаперечного втілення теоретичних ідей гуманізму в практику є благодійність, в усіх їі проявах. Вона виступає аксіологічною складовою суспільних відносин, що базуються на гуманістичних заса- 
дах у свідомості кожної людини. Навіть найзагальніше енциклопедичне тлумачення благодійності відповідно до якого в основі благодійності лежить намір проявити любов не лише до ближнього, але і до незнайомої людини, надати безоплатну матеріальну допомогу нужденним i соціально незахищеним громадянам $є$ відображенням сукупності дій в центрі яких $\epsilon$, преш за все, людина $з$ усіма іï моральними цінностями. На жаль, на сьогоднішній день аксіосфера суспільства трансформувалася і людська духовність деградує у руслі дегуманізації [3]. Але, в той же час, діяльність благодійників, які різними шляхами допомагають нужденними, $є$ показником практичних дій спрямованих на розвиток гуманності у суспільстві.

Погоджуємося 3 думкою К. Маркса, що мірилом гуманності людських відносин $є$ те, наскільки вони на практиці сприяють вирішенню нагальних завдань суспільного прогресу. Благодійна діяльність, зі всією палітрою людських відносин, виступає як практичний допоміжний механізм у вирішенні соціальних проблем громадян, як правило таких, що неспроможна вирішити держава.

Вирішення таких проблем можливо за умов формування основ громадянського суспільства. Його представники є самоорганізованою сферою свідомих громадян, що за мету своєї діяльності обрали особистий розвиток та самореалізацію в рамках досягнення суспільних позитивних звершень i, за необхідності, допомагають державі у виконанні іiі соціальних функцій [8]. Як бачимо, феномени громадянського суспільства та благодійності тісно взаємопов'язані, взаємовключені та взаємодоповнюючі один одного.

У нашому дослідженні ми розглядаємо благодійність, як універсальну загальнолюдську цінність, що є одним з найважливіших атрибутів громадянського суспільства, який стає інструментом, за допомогою якого суспільство задовольняє свої основні соціальні, загальнолюдські потреби. Окрім всього, благодійність громадянського суспільства є вагомими сегментом соціокультурного життя кожної країни [2].

Звернемо увагу на те, що діяльність активістів і організацій громадянського суспільства онтологічно є благодійною. Оскільки, їхні дії базуються, перш за все, на ціннісних орієнтирах спрямованих на покращення життя людини, як правило, на безоплатній основі. Іншими сло- вами, переважна більшість громадських діячів завжди є благодійниками, жертвуючи на благо інших свій найцінніший невідновний ресурси час та здоров'я. Окрім всього, благодійність $є$ повноправним соціальним інститутом громадянського суспільства, який законодавчо визначений та відповідає ключовим характеристикам інституту: соціальна підтримка нужденних, пошук шляхів консолідації суспільства, розвиток відносин соціальної солідарності, розвиток духовно-ціннісної сфери суспільства. Тому, основа будь-якої громадської діяльності $€$ благодійність.

Така практична громадська благодійна діяльності автентифікує одразу більшість тверджень гуманістичної філософії Ламонта. Зокрема, про те, що індивід досягає блага, гармонійно поєднуючи особисті бажання i безперервний саморозвиток з роботою, що робить внесок у добробут суспільства, а також положення, що люди мають здатність вирішувати власні проблеми, керуючись розумом і застосовуючи науковий метод.

Можемо $з$ упевненістю стверджувати, що в рамках громадянської благодійної діяльності необхідна реалізація восьмої тези Ламонта 3 обов'язковою підтримкою держави у вигляді довгострокової соціальної програми, яка передбачає встановлення в усьому світі демократії, миру і високого рівня життя [1, с. 148]. Адже, саме ці три базиси лібералізму $є$ підгрунтям свідомого гуманного суспільства в цілому.

Як бачимо феномен благодійної діяльності багатоаспектний. Але кожен ㄲï вид, незалежно від сфери діяльності, зокрема громадської, має різні ступені результативності у вирішенні соціальних проблем та формуванні умов для гуманізації суспільства. Ми пропонуємо наступну класифікацію основних форм благодійної діяльності: милостиня, гуманітарна допомога, філантропія, меценацтво та активна благодійність.

Вважаємо, доцільно відобразити вищезазначені види благодійності у вигляді ієрархічної піраміди, критеріями розміщення елементів якої $\epsilon$ створення найбільш сприятливих умов для практичного розвитку людини в цілому та їі гуманістичних якостей зокрема. 


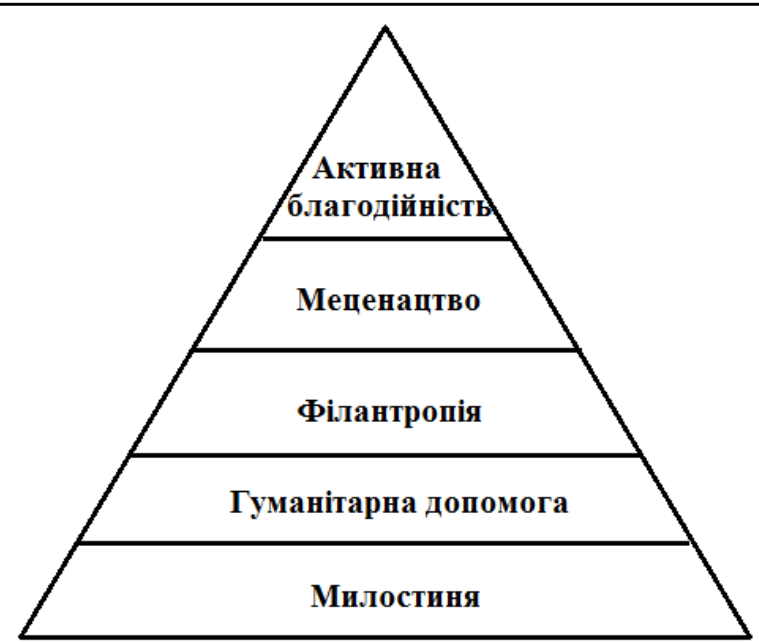

Рис.1. Ієрархічна піраміда благодійності

Рівень розташування кожної форми відповідає рівню потреб ієрархічної піраміди за Маслоу. Різниця полягає тільки в тому, що система Маслоу відображає ієрархію задоволення власних потреб, а класифікація форм благодійності показує глибину й об'єм задоволення потреб іншої людини, цим самим створюючи умови для розвитку та утвердження гуманізму в суспільстві.

Найнижчий рівень - милостиня та фізіологія; в обох ієрархіях на меті задоволення виключно фізіологічних потреб необхідних для виживання: їжа, вода, дім. Наступний рівень - гуманітарна допомога та безпека; визначає потребу в безпеці і полягає у асекурації засобів для життя, безкоштовно поширюваних серед населення районів, охоплених катастрофою або таких, що перебувають на іiі межі. Відрізняється від першого рівня більш ширшою сферою впливу. Третій рівень - філантропії та приналежності; виражає любов до людей та доброзичливе ставлення до людини взагалі, включає почуття приналежності до чого-небудь або кого-небудь. На відмінно від попередніх форм, характеризується постійною, відносно систематичною та широкою спрямованістю дій, а не одноразовою спеціально визначеною підтримкою. Четвертий рівень - меценацтво та повага; задовольняє потребу в особистих досягненнях, компетентності, повазі оточуючих, визнанні та приносить задоволення як благодійнику так і бенефіціару.

Вершина ієрархії - активна благодійність та самореалізація; задовольняє потреби в реалізації потенційних можливостей та зростанні особистості. Активна благодійність - це діяльність спрямована на практику здійснення благодійного внеску 3 метою досягнення максимально якісних, а не кількісних змін. Основою іiі діяльності $є$ створення таких умов, які сприятимуть усуненню джерела виникнення проблемної ситуації та запобігатимуть їх повторному виникненню. Це створення такого інструменту, що використовуватиметься безпосередньо нужденними самостійно i матимуть змогу особисто вирішувати власні проблемні ситуаціі. Саме таким чином формується основа i рушійна сила становлення гуманістичного, свідомого, вдячного суспільства.

Виходячи 3 даної ієрархії стверджуємо, що лише форма активної благодійності $є$ ціленаправленою, всесторонньою, системною та комплексною. Вона виступає одним 3 ефективних методів підтримки та розвитку добробуту населення створюючи умови для того, щоб гуманістична діяльність зайняла відповідне місце в ієрархії цінностей людини. Решта форм є обмеженими або не такими ефективними у вирішенні проблем соціального та гуманістичного характеpy.

Перебування суспільства на певному рівні ієрархії благодійності залежить від матеріальної спроможності громадян задовольняти свої потреби. Подаючи милостиню жебраку на вулиці ми лише на деякий час полегшуємо йому долю, так само як і задоволення потреб найнижчого рівня, але не сприяємо вирішенню ситуації в цілому. Таке «недовирішення» проблемної ситуації відбувається на кожному з рівнів, окрім активної благодійності. Це відбувається через те, що люди, які не мають фінансової можливості задовільнити особисті потреби перших чотирьох рівнів, так само не мають достатньо додаткових ресурсів, щоб реалізовувати себе та діяти в руслі гуманізації. Всі їхні сили спрямовані на здобуття, в основному, матеріальних, а не моральнодуховних цінностей.

Представники активної благодійності - це натхненні люди, які своєю діяльність привносять позитивні перетворення у сучасний світ невпинного розвитку технологій та поступової втрати самобутності існування; люди, які своєю роботою, усвідомлюючи всю важливість своєї свободи та рівень відповідальності за свої дії, спонукають мешканців планети Земля переглянути власні моральні цінності та докласти зусиль до підвищення рівня гуманізації відносин 
у суспільстві; люди, які серед тисячі негараздів здатні віднайти один позитивний момент, що рухає їх далі та дає їм сили заряджати інших людей. Це свідомі особистості, що керуються почуттями душі та моральними устоями, які поширюють серед інших. На жаль, таких людей не значна кількість. Але саме вони своїми діями роблять суспільство гуманним не лише теоретично, але й практично.

\section{Наукова новизна}

Наукова новизна роботи полягає в тому, що вперше було проведено комплексний аналіз взаємодії феноменів благодійності, гуманізму та громадянського суспільства. Окреслено взаємозв'язок методологічних підходів та різнопланових практичних версій розвитку благодійності та життєздатностей громадянського суспільства на основі гуманістичного принципу. Розроблена та запропонована до використання ієрархічна піраміда благодійності, критеріями розміщення елементів якої є створення найбільш сприятливих умов для практичного розвитку людини в цілому та іiі гуманістичних якостей зокрема, що співставлється та є прямозалежною 3 ієрархічною пірамідою потреб А. Маслоу. Введено та розтлумачено поняття «активна благодійність», як діяльність, що комплексно вирішує проблеми соціального характеру.

\section{Висновки}

Отже, гуманізм сучасної світової спільноти характеризується негомогенним рівнем розвитку та проблемами у процесі його становлення. Але, в той же час, теоретичні напрацювання в області вирішення даних питань $є$ достатньо обгрунтованими. Проте, відсутність постійної імплементації теорії у сферу практичної діяльності, призводить до виникнення та розповсюд- ження антигуманних дій. Одним із практичних шляхів побудови суспільства на принципах гуманності виступає благодійність, як інституційна та ресурсна складова громадянської діяльності. Однак, не всі форми благодійності є однаково ефективними. Представники практичного гуманізму знаходяться на найвищому щаблі ієрархічної структури благодійності - активного благодійництва. Інші чотири види - милостиня, гуманітарна допомога, філантропія, меценацтво, $€$ позитивними, але не виступають інструментом викорінення проблеми, а лише тимчасово покращують ситуацію. Враховуючи кореляційність $з$ класифікацією потреб Маслоу, де на вершині піраміди знаходяться фінансовостабільні особистості, фіксуємо показник матеріального забезпечення як обов'язковий та необхідний для становлення й стабільної підтримки гуманізму в суспільстві. Тому для того, щоб морально-ціннісний аспект існування суспільства мав можливість повноцінно функціонувати не тільки в теорії, а й на практиці потрібно працювати над забезпеченням достатнього розвитку демократії та високого рівня життя.

На сьогоднішній день розвиток громадської благодійної діяльності в Україні, що представлена волонтерством, гуманітарною допомогою воїнам АТО стає важливою сферою функціонування українського суспільства, але, на жаль, знаходиться тільки на другому рівні iєрархії, що в деяких місцях переходить в третій. Це $є$ показником того, що наша нація має хороше підгрунтя для розвитку гуманного суспільства, але недостатньо для того, щоб практично вирішувати проблеми військових та антигуманних дій на Україні.

\section{СПИСОК ВИКОРИСТАНИХ ДЖЕРЕЛ}

1. Андрієнко, О. В. Світоглядні виміри демократичного соціуму : монографія / О. В. Андрієнко; Донец. нац. ун-т. - Донецьк : ДонНУ, 2013. - 344 с.

2. Бакальчук, В. Механізм державного стимулювання благодійної діяльності у сфері культури : Портал «НІСД» / В. Бакальчук. - 2009. Режим доступу: http:// www.niss.gov.ua/Monitor/june2009/5.htm/. - Назва 3 екрану. - Перевірено: 31.03.2017

3. Bazaluk, O. The Problem of War and Peace: a Historical and Philosophical Analysis / O. Bazaluk // Philosophy and Cosmology - 2017. - Vol. 18. - C. 85-103.

4. Борзенко, И. М. Основы современного гуманизма: учебное пособие для студентов / И. М. Борзенко, В. А. Кувакин, А. А. Кудишина. - Москва: РГО, 2002. - 389 с. - Режим доступа: http://rudocs.exdat.com/docs/index-331532.html. - Перевірено: 31.03.2017 
5. Буркхардт, Я. Культура Италии в эпоху Возрождения: Опыт исследования / Я. Букхарт. - Москва : Интрада, 1996. - 306 с.

6. Красин, Ю. А. Новый гуманизм: метаидеология инновационной модернизации социума // Мировой социально-политический процесс и идеология гуманизма XXI века : монография / колл. авторов. - Москва: Издательство Русайнс, 2015. - С. 77-104.

7. Новиков, Б. В. Гуманизм, духовность, в современном информационном обществе / Б. В. Новиков // Народна освіта: електронне фахове видання. - 2008. - Вип. 1 (4). - Режим доступу: https://narodnaosvita.kiev.ua/Narodna_osvita/vupysku/4/statti/1novikov.htm - Назва 3 екрану. - Перевірено: 31.03.2017

8. Hovnannisyan, H. Idea and Models of Civil Society: Development Tendencies, Arguments Pro and Con / H. Hovnannisyan // ResearchGate. - 2016. - Access Mode : https://www.researchgate.net/publication/314866578_Idea_and_Models_of_Civil_Society_Development_Tende ncies_Arguments_Pro_and_Con. - Title from Screen.-Date of Access: 31 March 2017.

9. Kurtz, P. The courage to become: the virtues of humanism / P. Kurtz. - Westport, Conn. : Praeger, 1997. $138 \mathrm{p}$.

10. Lamont, C. The philosophy of humanism. - London, 1961. - 243 p.

11. Smith, W. A. Who's who in hell: A handbook a. international directory for humanists, freethinkers, naturalists, rationalists a. non-theists / W. A. Smith. - New York, 2000. - 1237 p.

\title{
М. М. ЖИТНИК ${ }^{1 *}$
}

$1^{*}$ Национальный технический университет Украины «Киевский политехнический институт имени Игоря Сикорского» (Киев), эл. почта Maryna_zhytnyk@i.ua, ORCID 0000-0003-3374-0091

\section{БЛАГОТВОРИТЕЛЬНОСТЬ В ПРОЦЕССЕ ФОРМИРОВАНИЯ ГУМАНИСТИЧЕСКОЙ АКВИОСФЕРЫ ГРАЖДАНСКОГО ОБЩЕСТВА}

Целью работы является характеристика благотворительности как составляющей гражданского общества, развивающегося на основе принципа гуманизма в современном обществе. Методология статьи основывается на комплексном направлении исследований в диалектическом взаимодействии триалога единичного, особенного и общего, что позволило рассмотреть отдельные явления в развитии и взаимосвязи, единстве и противоречии, в частности при изучении и анализе отдельных понятий. С целью мнимого ухода от несущественных свойств, связей, характеризующих отдельные понятия, с одновременным выделением их важнейших черт был использован метод абстрагирования и индукции. Научная новизна работы заключается в том, что впервые была обозначена взаимосвязь методологических подходов и разноплановых практических версий развития благотворительности и возможностей гражданского общества на основе гуманистического принципа. Разработана и предложена к использованию иерархическая пирамида благотворительности, критериями размещения элементов которой является создание наиболее благоприятных условий для практического развития человека в целом и ее гуманистических качеств в частности, что сопоставляется и является прямо зависимым с пирамидой потребностей А. Маслоу. Введены и разъяснены понятия «активная благотворительность» как деятельность, комплексно решающая проблемы социального характера. Выводы. Благотворительность, как институциональная и ресурсная составляющая гражданской деятельности, выступает одним из практических путей построения общества на принципах гуманности. Однако, не все формы благотворительности одинаково эффективны. Представители активной благотворительности, наивысшей ступени иерархической структуры благотворительности - это финансовостабильные, сознательные личности, которые непосредственно выступают практиками гуманизма и являются наиболее эффективными.

Ключевые слова: благотворительность; гражданское общество; гуманизм; евпраскофия; иерархическая пирамида благотворительности; активная благотворительность.

\author{
M. M. ZHYTNYK ${ }^{1^{*}}$ \\ 1* National Technical University of Ukraine «Igor Sikorsky Kyiv Polytechnic Institute»(Kyiv), e-mail Maryna_zhytnyk@i.ua, \\ ORCID 0000-0003-3374-0091
}




\section{CHARITY IN THE PROCESS OF FORMING THE HUMANIST AXIOSPHERE OF CIVIL SOCIETY}

Purpose. The research characterizes the charity as part of civil society, which develops based on humanism in modern society. Methodology of the article is based on the complex direction of research in the dialectical interaction of the triad of a single, a special and a general that allowed to consider certain phenomena in development and interconnection, unity and contradiction, in particular, in the study and analysis of individual concepts. The author used the method of abstraction and induction with the purpose of imaginary departure from the nonessential properties and connections characterizing individual concepts, with simultaneous isolation of their most important features. Originality. The author for the first time in this work has designated the interrelation between methodological approaches and diverse practical versions of the development of charity and the opportunities of civil society based on the humanistic principle. The paper presents the developed and ready for use hierarchical pyramid of charity, the criteria for placing elements of which is the creation of the most favorable conditions for the practical development of human in general and his humanistic qualities in particular, which is directly correlated with the Maslow pyramid of needs. The author has introduced and explained the notion of «active charity», as an activity that comprehensively solves social problems. Conclusions. Charity, as an institutional and resource component of civic activity, acts as one of the practical ways of building a society on the humanity principles. However, not all forms of charity are equally effective. Representatives of active charity, the highest level of the hierarchical structure of charity, are financially stable, conscious individuals who directly act as practitioners of humanism and become most effective.

Keywords: charity; civil society; humanism; eupraskophy; hierarchical pyramid of charity; active charity.

\section{REFERENCES}

1. Andriienko, O. V. (2013). Svitohliadni vymiry demokratychnoho sotsiumu. Donetsk: DonNU. (In Ukranian)

2. Bakalchuk, V. (2009). Mekhanizm derzhavnoho stymuliuvannia blahodiinoi diialnosti u sferi kultury: Portal «NISD». Retrived from: http:// www.niss.gov.ua/Monitor/june2009/5.htm/. Accessed March 31, 2017. (In Ukranian)

3. Bazaluk, O. (2017). The Problem of War and Peace: a Historical and Philosophical Analysis. Philosophy and Cosmology, 18, 85-103. (In English)

4. Borzenko, I. M., Kuvarkin, V. A., \& Kudishina, A. A. (2002). Osnovy sovremennogo gumanizma: uchebnoe posobie dlya studentov. Moscow: RGO. Retrived from http://rudocs.exdat.com/docs/index-331532.html. Accessed March 31, 2017. (In Russian)

5. Burkkhardt, Ya. (1996). Kultura Italii v epokhu Vozrozhdeniya: Opyt issledovaniya. Moscow: Intrada. (In Russian)

6. Krasin, Yu. A. (2015). Novyy gumanizm: metaideologiya innovatsionnoy modernizatsii sotsiuma. Mirovoy sotsialno-politicheskiy protsess $i$ ideologiya gumanizma XXI veka (pp. 77-104). Moscow: Izdatelstvo Rusayns. (In Russian)

7. Novikov, B. V. (2008). Gumanizm, dukhovnost, v sovremennom informatsionnom obshchestve / B. V. Novikov. Narodna osvita: elektronne fakhove vidannya. 1(4). Retrived from https://narodnaosvita.kiev.ua/Narodna_osvita/vupysku/4/statti/1novikov.htm. Accessed March 31, 2017. (In Ukranian)

8. Hovnannisyan, H. (2016). Idea and Models of Civil Society: Development Tendencies, Arguments Pro and Con. ResearchGate. Retrived from

https://www.researchgate.net/publication/314866578_Idea_and_Models_of_Civil_Society_Development_Tende ncies_Arguments_Pro_and_Con. Accessed March 31, 2017. (In English)

9. Kurtz, P. (1997). The courage to become: the virtues of humanism. Westport, Conn.: Praeger. (In English)

10. Lamont, C. (1961). The philosophy of humanism. London. (In English)

11. Smith, W. A. (2000). Who's who in hell: A handbook a. international directory for humanists, freethinkers, naturalists, rationalists a. non-theists. New York. (In English)

Стаття рекомендована до публікаиії д. філ. н., проф. О. В. Корабльовою (Україна)

Надійшла до редколегії: 10.12 .2016

Прийнята до друку: 5.10.2017 